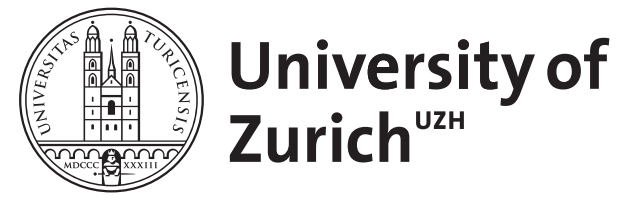

Zurich Open Repository and Archive

University of Zurich

University Library

Strickhofstrasse 39

CH-8057 Zurich

www.zora.uzh.ch

Year: 2017

\title{
Lynda Mugglestone. Samuel Johnson and the Journey into Words
}

Reddick, Allen

DOI: https://doi.org/10.1093/ijl/ecw009

Posted at the Zurich Open Repository and Archive, University of Zurich

ZORA URL: https://doi.org/10.5167/uzh-133696

Journal Article

Published Version

Originally published at:

Reddick, Allen (2017). Lynda Mugglestone. Samuel Johnson and the Journey into Words. International Journal of Lexicography, 30(3):382-387.

DOI: https://doi.org/10.1093/ijl/ecw009 


\section{REVIEW}

Lynda Mugglestone. 2015. Samuel Johnson and the Journey into Words. Oxford: Oxford University Press. xii +290 pages. ISBN 978-0-19-967990-4 hardback. Price 25.00 GBP.

This eloquent and wide-ranging study ${ }^{1}$ begins with an examination of the metaphors involving voyaging by sea and traveling more generally that lexicographers use in discussing and describing their work. The 'Journey into Words' of the title invokes a voyage, even a pilgrimage, as well as a penetration and exploration of what turns out to be 'a Sea of words' (Johnson quoting from Warburton's reflection on his 1747 Shakespeare, adapting the phrase, in turn, from John Florio's 1598 Worlde of Words). Past writers on language, Lynda Mugglestone makes clear, have habitually used these images and a variety of similar metaphors having to do with movement, boundaries, self, and other, as well as protection and incursion. Mugglestone's tracing of Johnson's metaphors opens up a variety of important insights into his lexicographical attitudes and practices. A key example is that of the citadel, a fortress or castle, where arms are kept, from which Johnson imagines carrying on 'a war in which words - as both territory and ammunition - are paramount' (p. 141). She outlines the images of warfare and travel, introducing an examination of eighteenth-century approaches to loanwords and foreign borrowings. These she places in a context of contemporary English concerns about invasion, identity, defense, and suppression, especially concerning France and the French. Johnson pays careful attention to Addison's alarms concerning the threats of French to the English language: he quotes Addison's cautions under adulterate, for example, defined as 'To corrupt by some foreign admixture; to contaminate' (p. 143). Lord Chesterfield's letter to The World in November 1754, puffing Johnson's immanent Dictionary, remarks, 'The time for discrimination seems to be now come. Toleration, adoption and naturalization have run their lengths'. Mugglestone demonstrates the ways in which Johnson shares some of these historical and ideological positions in the Plan of a Dictionary (1747) and the 'Preface to the Dictionary' (1755). As we in today's world well know, 'Language and national anxieties,' as she notes, 'easily combine' (p. 145). To Frenchify, Johnson defines as: 'To infect with the manner of France; to make a coxcomb'. Johnson seems to agree with Chesterfield (in the 'Preface', at least) about the need to make attempts to protect the English language. He will endeavor to 'recal' English from invasions and importations: his work will be English, relying upon the authority of writers whose works provide 'the wells of English undefiled' (p. 146, quoting Johnson's 'Preface'). 
Mugglestone turns her empirical eye from Johnson's comments in the Plan and 'Preface' to his lexicographical text itself. She lists numerous examples in which Johnson censures words for being more French (Gallicisms) than English, 'innovated from France, without necessity' (p. 149). She writes of Johnson's utilization of an auxiliary class of words, designated as such by being printed in italics, that 'remained, for Johnson, resonant of the unassimilated "other" whose identity as "auxiliary" resides in another country entirely" (p. 151). Yet this is not the end of the story. Mugglestone invokes Isabel Balteiro's concept of 'descriptive prescriptivism' to consider the limits to Johnson's defense of the 'citadel' in practice (p. 151). Johnson recognizes and incorporates 'the on-going momentum of change' and the evidence for it (p. 152).

The thoroughness of Mugglestone's analysis reveals the nuances of Johnson's positions on loanwords and foreign borrowings. Johnson's Plan speaks of 'the state of aliens'-foreign words used in English speech yet not at all assimilated - that is, as Mugglestone describes it, 'the retention of nonnative phonology, spelling, or morphology indicates, as Johnson carefully explains, that "no approaches towards assimilation" have been made' (p. 153). In other words, as Mugglestone makes clear, 'Johnson's metalanguage draws attention to the absence of assimilation' (p. 156). Yet some French words can be naturalized: phenomenon, sublime, and verdant are examples at other points along the spectrum; or adroitness and adroit at another point in the line of change. 'Against Chesterfield's desire for certainty', Mugglestone writes, 'Johnson's fondness for hedges such as "seems", alongside his patterns of temporal qualification, can again carefully focus attention on the possibilities of on-going change and variation' (p. 156).

She traces Johnson's position elsewhere on the prescriptive and descriptive spectrum concerning loans and lexical borrowing, especially from French. He describes certain individual lexemes correctly as English, though they retain the tenor and idiomatic usage as French (e.g. glossing Dryden's 'By one rebellious act renounces to my blood' as 'a mere Gallicism,' from the French renoncer a mon sang [p. 157]). Johnson describes usage as he finds it. Mugglestone's examination of Johnson's practice of examining and censuring peculiar usages of naturalized words (e.g., Dryden's use of falsify, relying, as Johnson notes, on the Italian falsare) reveals his insistence that the criterion for nationalization is reception, not the ingenuity of the poet. Nevertheless, Johnson is remarkably tolerant: as Mugglestone notes, toleration is defined in the Dictionary as 'Allowance given to that which is not approved'. 'Johnson's treatment of loanwords', Mugglestone concludes, 'can incline to the dynamics of registering rather than forming, as well as regulating "absurdity" when necessary' (p. 163).

As this summary should demonstrate, Mugglestone's discussions are thorough, keen-eyed, well-contextualized, and eloquent. A further example will strengthen these impressions. Mugglestone examines, in a particularly strong 
section, Johnson's position on orthography. She takes on the 'popular mythography' (p. 97) of the Dictionary's conservative insistence upon fixity and stability in spelling, represented here by quotations from Lawrence Lipking and David Crystal. Reading the Plan, she demonstrates that, rather than an adherence to fixity and normativity for their own sake, Johnson is reluctant 'to introduce changes which have no basis in actual usage' (p. 98). In other words, how do most writers in English spell their words? They may vary, but Johnson tries to decide according to 'the general custom of our language'. While in the headwords and commentary under entries he may indicate his preference, based on analogy and/or etymology, for certain spellings that are less common (such as gelly not jelly, or intrinsecal, not intrinsical), he nevertheless makes clear that many other writers, perhaps a majority, disagree with his preferences. The lexeme jelly, Mugglestone informs us, 'gains an entry of its own, supported by evidence and appropriate citations from Shakespeare, King, and Pope' (p. 102), while intrinsical is noted by Johnson as the general spelling and, as Mugglestone argues, 'supporting information can already suggest [to Johnson and his readers] that victory, at least quantitatively, might lie in another direction entirely' (p. 101) from his own preference. A similar case is provided for gaol/jail. 'Johnson's metalanguage - and a pervasive habit of hedging ("perhaps", "sometimes") in the comments that he makes - can, as a result, often sit at odds with the narratives of reform and imposed power that Chesterfield, and others, awaited' (p. 104). Mugglestone illustrates her observation with multiple examples of Johnson's 'hedging' and references to the importance of 'custom' (p. 105). 'Seen from this position', Mugglestone concludes, speaking specifically of spelling, 'Johnson's text does not suggest a writer who was unduly preoccupied either with control or conquest' (p. 108).

Mugglestone's analysis of other aspects of Johnson's lexicographic practice and his general attitudes towards language argues consistently for a more 'liberal' Johnson in these regards than scholarship has often found. Instead, his tendencies, she argues convincingly, are more often against normative approaches. He is remarkably non-prescriptive, believing, for example, that language usage changes in response to custom. Johnson's comments and practice, Mugglestone avers, reveal that, 'Bound to cycles of budding and falling away, language is seen as fundamentally regenerative' (p. 203). In these ways she explicitly agrees with Patrick Hanks's view that Johnson emerges 'as a thoroughly "modern" lexicographer' (p. 203). I find her evidence supporting this claim, mustered throughout the book in a variety of aspects, both convincing and refreshing.

A fruitful area of research remains the relation of Johnson's theory and practice of literary criticism to his lexical and lexicographical work. Mugglestone makes insightful forays into this area. One such is her discussion of Johnson's entry for peal, in which he claims it was improperly used by Shakespeare 'for a low dull tone': 'The shard-borne beetle with his drowsy hums / Hath rung night's 
yawning peal' (Macbeth, act III). Johnson defines the word plausibly as: 'A succession of loud sounds: as, of bells, thunder, cannon, loud instruments', with several literary authorities to back him up. 'Shakespeare's creative departure..., writes Mugglestone, 'fractures this shared sense of meaning' (p. 125). Similarly, in Henry VI, part II, Shakespeare uses 'pilgrimage' to denote 'time irksomely spent', as Johnson's definition glosses the following example: 'In prison thou hast spent a pilgrimage, / And, like a hermit, overpast thy days'. Johnson insists that the conventional meaning is correct: 'A long journey; travel; more usually a journey on account of devotion'. Shakespeare's usage is idiosyncratic, and not to be repeated by others; but, as Mugglestone's discussion makes plain, Johnson's censures paradoxically illuminate Shakespeare's brilliant, singular, transformative uses of poetic language.

A corollary of Johnson's increasing tendency away from prescription towards description of language use is the extent to which his definitions and notes on usage represent records of his critical responses to specific passages and authors, constituting a version of literary criticism. It would be interesting to follow Mugglestone's thoughts in this area of investigation. Moreover, one can't help but wish that she had engaged more thoroughly with questions of voice and authority represented by quotations included in the Dictionary. The status - tonal or rhetorical, for instance - of the quotations inserted as authorities is too often taken for granted in Mugglestone's discussions. If Dryden, for example, is quoted in the Dictionary, does he necessarily speak in his own voice within the new context of the Dictionary entry? Does the quotation retain reminders or markers of its original context? Do the quotations and their authors voice Johnson's own views on matters other than language use? What is the relation of the quotation and the author quoted to any other quotations and their authors? Is the relation always stable and predictable from one case to the next?

Mugglestone includes an appendix that suggests future possibilities for her investigations, yet its contours are merely sketched. Entitled 'Appendix: 175573', this section represents her interest in Johnson's changing attitudes towards language over time, and his developing lexicographical practice; however, it also exposes her lack of full command of the subject. The appendix helpfully cites several examples from the revision of the Dictionary for the heavily-revised fourth edition of 1773 . These examples are limited to a few entries with added quotations, definitions and comments on usage. In no case, unfortunately, does she examine the revisions of an entry as a whole, assessing the changes in relation to each other and examining the nature and effect of the added quotations in relation to the entry as a whole. Scholarship on the 1773 revision has examined extensively the peculiar quality of Johnson's incorporation of new quotations into the fourth edition [e.g. Reddick 1996, 1997]. One hopes that Mugglestone will in a future publication embed her findings in a fuller investigation of Johnson's revisions over time. 
Her hints towards this end are tantalizing. Citing Reddick's conclusions that Johnson incorporated into his revised edition a number of politico-theologically conservative sources for his authorities, she comments that such ideological conservatism is "one which is, at times, also mirrored in the linguistic stance which can be assumed" (p. 259, n. 8). Why, on what basis, can this be assumed? Similarly, she cites analysis [Reddick 1997] that has demonstrated that the text from 1755 to 1773 has become more conservative (in relation to the added politico-theologically conservative authorities) and then freely applies that conservatism to a change in Johnson's attitude towards language itself (p. 213). Why should this position be assumed? The examination of Johnson's new sources, at first glance, seem to have very little to do with his linguistic position. While both these suggestions are worth pursuing, no evidence or elaboration are offered.

The appendix displays evidence of hasty preparation. She mistakes the first two abridged editions (2-vol. octavos, 1756 and 1760, intended for 'the common reader') for the second and third editions, respectively, of the folio Dictionary. Johnson refers to 'A new edition of my great Dictionary', using 'great' to distinguish it from 'abstracted' or abridged (p. 209). The surname of Johnson's amanuensis is misspelled ('Macbean' is the accepted spelling). These mistakes will certainly be corrected in a subsequent edition or examination of the subject.

It is rare to find a scholar fully proficient in the history of lexicography and historical linguistics who also knows Johnson as a biographical subject and is familiar with the range of his writing. And who writes so engagingly. Lynda Mugglestone has written a book of erudition, critical ability, and appreciation of her topic in a wide cultural context. It is worthy of her subject.

\section{Notes}

1 I have also reviewed this book with somewhat different emphases for the Review of English Studies.

\section{References}

\section{A. Dictionaries}

Florio, John. 1598. A Worlde of Wordes, or Most Copious, and Exact Dictionarie in Italian and English. London: Edward Blount.

Johnson, Samuel. 1755. A Dictionary of the English Language; in which the words are deduced from their originals and illustrated in their different significations by examples from the best writers. London: J. and P. Knapton, T. and T. Longman, C. Hitch and L. Hawes, A. Millar, and R. and J. Dodsley. [2nd ed. 1756; 3rd ed. 1765; $4^{\text {th }}$ ed. 1773].

Johnson, Samuel. 1755. A Dictionary of the English Language... Abstracted from the Folio Edition. London: J. Knapton, C. Hitch and L. Hawes, A. Millar et al. [2 ${ }^{\text {nd }}$ ed. 1760].

Kolb, Gwin J. and Robert DeMaria, Jr. (eds). 2005. Johnson on the English Language. New Haven: Yale University Press. [includes Plan of a Dictionary and 'Preface']. 


\section{B. Other literature}

Balteiro, Isabel. 2011. 'Prescriptivism and Descriptivism in the Treatment of Anglicisms in a Series of Spanish-English Dictionaries.' International Journal of Lexicography 24.3: 277-305.

Crystal, David. 2012. Spell it Out: the Singular Story of English Spelling. London: Profile Books.

Hanks, Patrick. 2005. 'Johnson and Modern Lexicography.' International Journal of Lexicography 18.2: 243-66.

Johnson, Samuel. 1992-94. The Letters of Samuel Johnson, ed. Redford Bruce. 5 vols. Oxford: Oxford University Press.

Lipking, Lawrence. 1998. Samuel Johnson: the Life of an Author. Cambridge, Mass.: Harvard University Press.

Pope, Alexander and William Warburton, (eds). 1747. The Works of Shakespeare, vol. I. London: J. and P. Knapton, S. Birt, et al.

Reddick, Allen. 1996. The Making of Johnson's Dictionary, 1746-1773, $2^{\text {nd }}$ revised edn. Cambridge: Cambridge University Press.

Reddick, Allen. 1997. 'Johnson beyond Jacobitism: Signs of Polemic in the Dictionary and the "Life of Milton".' ELH 64.4: 983-1005.

[Stanhope, Philip Dormer, Lord Chesterfield]. 1754. Letter to The World No. 100 (28 November).

Allen Reddick

University of Zürich

reddick@es.uzh.ch

doi:10.1093/ijl/ecw009 